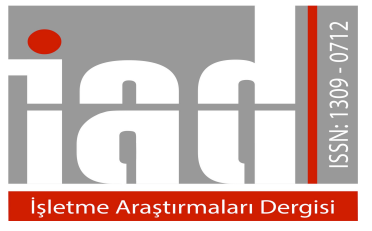

Journal Of

Business Research

Turk

www.isarder.org

\title{
Sağlık İşletmelerinde Performansa Dayalı Ek Ödeme Sistemi (PDEÖS) ve Maliyetlere Etkisi: Ankara Dışkapı Yıldırım Beyazıt Eğitim ve Araştırma Hastanesi Örneği ${ }^{1}$
}

\author{
Performance Based Supplementary Payment System (PBSPS) in Health \\ Care Businesses and Its Effects on Costs: The Case of Ankara Dışkapı \\ Yuldırım Beyazıt Training and Research Hospital
}

\author{
Seyhan ÇİL KOÇYİĞíT \\ Gazi Üniversitesi \\ İktisadi ve İdari Bilimler Fakültesi \\ Sağlık Yönetimi Bölümü, \\ Ankara, Türkiye \\ seyhanc@gazi.edu.tr
}

\author{
Nursen KARADOĞAN \\ Gazi Üniversitesi \\ Sosyal Bilimler Enstitüsü, \\ Hastane İşletmeciliği Bölümü, \\ Ankara, Türkiye \\ k.nursen12335@gmail.com
}

\section{Özet}

Çalışmanın amacı, 21.01.2010 tarihli 5947 Sayılı Tam Gün Kanunu'nun, Sağlık Bakanlığı Ankara Dışkapı Yıldırım Beyazıt Eğitim ve Araştırma Hastanesi'nin 20092015 yıllarına ait ek ödeme tutarları ve toplam maliyet tutarları üzerindeki etkisini araştırmaktır. Çalışmada sözkonusu hastanenin, 2009-2015 yıllarına ait ek ödeme tutarları ve toplam maliyet tutarları, 2015 yılı yurt içi üretici fiyat endeksi ile düzeltilmiş ve 2009 yılı baz yıl seçilerek trend analizi yapılmıştır. Ayrıca çalışmada, performansa dayalı ek ödeme sistemi (PDEÖS) de ele alınmıştır. Çalışma sonucunda; 2009 baz yıla göre ek ödeme tutarlarının 2013 yılından itibaren arttığı, toplam maliyetlerin de baz yıla göre bütün y1llarda sürekli azaldığı tespit edilmiştir.

Anahtar Kelimeler: 5947 Sayılı Tam Gün Kanunu, Performans, Performansa Dayalı Ek Ödeme Sistemi, Ek Ödeme Tutarları, Maliyet

\section{Abstract}

Objective of study is to search the effect of the Full-Time Law No.5947 dated 21.01.2010 on the amounts of the supplementary payment and the amounts of total cost of the Ministry of Health Ankara Dışkapı Yıldırım Beyazıt Training and Research Hospital, for the years between 2009-2015. In this study, the amounts of the

$1 \mathrm{Bu}$ çalışma, Doç. Dr. Seyhan ÇİL KOÇYİĞi̇T danışmanlığında yürütülen, Nursen KARADOĞAN'ın "Sağlık İşletmelerinde Performansa Dayalı Ek Ödeme Prim Sistemi ve Maliyetlere Etkisi: Ankara Dışkapı Yıldırım Beyazıt Eğitim ve Araştırma Hastanesi Örneği” adlı yüksek lisans tezinden türetilmiştir. 
supplementary payment and amounts of total cost of the said hospital, pertaining to 2009-2015, have been adjusted by the domestic producer price index of 2015 and a trend analysis has been made through the selection of the base year of 2009 . Additionally in this study, the performance based supplementary payment system (PBSPS) has been discussed. In the result of the study has been showed that the amounts of the supplementary payment have increased since 2013, in reference to the base year of 2009 and that the total costs have continuingly decreased in all years when compared to the base year.

Keywords: Full-Time Law No.5947, Performance, Performance Based Supplementary Payment System, Amounts of Supplementary Payment, Cost

\section{Giriş}

Performansa dayalı ek ödeme sistemi (PDEÖS), Sağlık Bakanlığı'na bağlı tüm sağlık tesislerinde uygulanmakta olan, Bakanlıkça belirlenen hizmet sunum şartları ve kriterleri de dikkate alınmak üzere, sağlık hizmetlerinin iyileştirilmesi, kaliteli ve verimli hizmet sunumunun teşvik edilmesinin sağlanması amacıyla, görevli personele döner sermaye gelirlerinden yapılacak ek ödemenin oran, usul ve esaslarını belirleyen bir sistemdir.

2003 Yılında 'Sağlıkta Dönüşüm Programı'nın", hayata geçirilmesiyle birlikte sistem konusunda ilk çalışmalar başlatılmıştır. Sistem, 2004 yılının başından itibaren tüm Sağlık Bakanlığı tesislerinde uygulanmaya başlanmıştır. Sisteme, 2005 yılında kurumsal performans ölçütleri, 2010 yılında yönetici performans ölçütleri, 2011 yılında da birim performans kriterleri eklenmiştir.

Performansa dayalı ek ödeme sistemi (performansa dayalı döner sermaye prim sistemi), kamuoyunda 'Tam Gün Kanunu" olarak da bilinen, 21.01.2010 tarihli 5947 sayılı kanundan etkilenmiştir. Bu çalışmanın konusunu, Tam Gün Kanunu'nun, hastane sağlık personelinin ek ödeme tutarlarına ve toplam maliyetlere olan etkisinin araştırılması oluşturmaktadır.

21.01.2010 tarihli 5947 Sayılı Tam Gün Kanunu, üniversitede çalışan öğretim üyeleriyle, kamuda çalışan hekimlerin, özel bir sağlık kuruluşunda ya da kendilerine ait özel muayenehanelerinde çalışamayacaklarıyla ve kamuyu tercih etmeleri taktirde, ek ödemelerinde yapılacak iyileştirmeyle ilgilidir. Bu araştırmada da, Sağlık Bakanlığ Ankara Dışkapı Yıldırım Beyazıt Eğitim ve Araştırma Hastanesi'nin 2009-2015 yıllarına ait ek ödeme tutarları ve toplam maliyet tutarları incelenmiştir.

Araştırma da öncelikle döner sermaye ve döner sermayeli işletmeler ele alınmıştır. Daha sonra, performans kavramı ve sağlık kurumlarında PDEÖS, PDEÖS'ün işıleyişi, PDEÖS'ün güçlü ve zayıf yönleri, Tam Gün Kanunu ve bu kanunda yapılan çalışmalar incelenmiştir. Son olarakta uygulamaya yer verilmiştir. Araştırmada, Sağlık Bakanlığ 1 Ankara Dışkapı Yııldırım Beyazıt Eğitim ve Araştırma Hastanesi'nin 2009-2015 yıllarına ait ek ödeme tutarlarının, toplam maliyet tutarları üzerindeki etkisi araştırılmıştır. Analizde, 2009-2015 yıllarına ait ek ödeme tutarları ve toplam maliyet tutarları, 2015 yılı yurt içi üretici fiyat endeksi ile düzeltilmiş ve 2009 yılı baz yıl seçilerek trend analizi yapılmıştır. 


\section{Döner Sermaye ve Döner Sermayeli İşletmeler}

Döner sermaye ve döner sermayeli işletmeler ile ilgili literatürde çeşitli tanımlamalara rastlamak mümkündür.

Genel ve katma bütçeli idarelerin kamu hizmetlerinin yerine getirilmesi sırasında, bu hizmetlere bağlı olarak yönetilen ticari, sınai, tarımsal, kültürel ve mesleki nitelikteki faaliyetlerinin yürütülmesi için tahsis edilen sermayelere "döner sermaye', bu şekilde kurulan işletmelere de 'döner sermayeli işletmeler'" denilmektedir (Kostik, 1998, s. 11).

Diğer bir tanımda; döner sermaye; genel yönetim kapsamındaki kamu idarelerine kanunlarla verilen asli ve sürekli kamu görevlerine bağlı olarak ortaya çıkan ve genel idare esaslarına göre yürütülmesi mümkün olmayan mal ve hizmet üretimine ilişkin faaliyetlerin sürdürülebilmesi için, kamu idaresine bağlı olarak kurulmuş işletmelere tahsis edilen sermaye olarak ifade edilmektedir. Bu tanım uyarınca verilen sermayenin tahsis amacını gerçekleştirmek üzere kurulan işletmelere de döner sermayeli işletmeler denir (Maliye Bakanlığı Muhasebat Genel Müdürlüğü [MBMGM], Döner Sermayeli İşletmeler Bütçe ve Muhasebe Yönetmeliği, 2007, s. 1).

Döner sermayeli işletmelerin genel özellikleri aşağıdaki gibi sıralanabilmektedir: olarak,

- Ana kuruluş olan genel, katma veya özel bütçeli idare ve kurumlara bağlı kanunla kurulurlar.

- Genellikle tüzel bir kişiliğe sahip değildirler.

- Sermayeleri, bağlı oldukları idarenin verdiği ödenekler ve işletmekarlarından oluşur.

- İşletme bütçesi yıllık olarak hazırlanır, bağlı oldukları kuruluşun onayındansonra yürürlüğe girer.

- Çoğu, 1050 sayılı Muhasebe-i Umumiye Kanunu'na tabi değildirler. kişiler,

- Denetimleri, bağlı oldukları kuruluşun üst amirleri veya görevlendireceği

Maliye Bakanlığı ve Sayıştay tarafından yapılır.

- Ticari işlemleri ve işleri hakkında '’T.T.K, B.K.' hükümleri uygulanır.

- Devletle olan ilişkilerinde kamu hukukuna giren kanun hükümleri uygulanır.

- Sözleşmeli işçi çalıştırmaları halinde, toplu ve bireysel iş hukuku hükümleri ile S.G.K. hükümlerine tabi bulunurlar.

Üniversiteler ve bağlı birimleri (fakülte, yüksekokul, enstitü vb.) katma bütçeli daireler içinde yer alan kurumlardır. Bu çerçevede, üniversiteler ve bağlı birimlerinde faaliyet göstermek üzere de, döner sermayeli işletmeler kurulabilmektedir (Şakrak, 1997, s. 19-20). 
Kamu mali sistemimize yön veren 5018 Sayılı Kamu Mali Yönetimi ve Kontrol Kanunu, 01.01.2006 tarihi itibariyle yürürlüğe girmiştir. Döner sermaye işletmeleriyle ilgili en son düzenleme 5018 sayılı Kamu Mali Yönetimi ve Kontrol Kanunu'nun geçici 11. maddesidir. $\mathrm{Bu}$ düzenleme ile döner sermaye işletmelerinin 31.12.2007 tarihi itibarıyla tasfiye edilmesi ve tasfiyeye ilişkin esas ve usullerin Bakanlar Kurulu'nca çıkarılacak bir yönetmelikle belirlenmesi öngörülmüş ise de ilgili maddede yapılan değişikliklerle bu tarih 31.12.2010'a uzatılmıştır (Kartalc1, 2012, s.111). Günümüzde ise genel ve özel bütçeli idarelere bağlı döner sermayeli işletmelerinin tamamının harcama ve muhasebe işlemlerini kapsayacak web tabanlı bir sistem ile aynı kapsamda yönetim bilgi sisteminin kurulması içinDöner Sermaye Mali Yönetim Sistemi (DMIS) geliştirilmiş ve bu sistemle döner sermayeli işletmelerin bütçe, muhasebe, harcama, personel, gelir ve taşınır işlemlerin yürütülmesini sağlayan ortak bir web tabanlı uygulama yazılımı ile yöneticilerin sağlıklı, hızlı ve doğru karar vermelerine imkân veren bir yönetim bilgi sisteminin kurulması amaçlanmiştir (http://www.dmisproje. muhasebat.gov.tr/2014, erişim 3 Ocak2016).

Günümüzde, genel ve özel bütçeli idarelere bağlı döner sermayeli işletme sayıları ve muhasebe birim sayıları ise Tablo 1' de görülmektedir.

Tablo 1: Genel ve Özel Bütçeli İdarelere Bağlı Döner Sermayeli İşletme Sayıları ve Muhasebe Birim Sayıları

\begin{tabular}{|c|c|c|}
\hline İDARE ADI & İŞLETME SAYISI & MUHASEBE BİRIMM SAYISI \\
\hline Sağlık Bakanlığı & 1.074 & 174 \\
\hline Milli Eğitim Bakanlığ1 & 780 & 437 \\
\hline Orman Genel Müdürlüğü & 301 & 301 \\
\hline $\begin{array}{c}\text { Gida, Tarım ve Hayvancılık } \\
\text { Bakanlığ }\end{array}$ & 191 & 191 \\
\hline Orman ve Su işleri Bakanlığ 1 & 92 & 92 \\
\hline Üniversiteler & 103 & 58 \\
\hline Milli Savunma Bakanlığı & 59 & 59 \\
\hline Aile ve Sosyal Politikalar Bakanlığ & 83 & 54 \\
\hline Diğer İdareler & 20 & 17 \\
\hline TOPLAM & 2.703 & 1.383 \\
\hline
\end{tabular}

Tablo 1'de görüldüğü gibi en fazla döner sermayeli işletme ve muhasebe birim sayısı, Sağlık Bakanlığı’na aittir. Sağlık Bakanlığı'nı sırasıyla, Milli Eğitim Bakanlığı ve Orman Genel Müdürlüğü takip etmektedir.

\section{Performas Kavramı ve Sağlık Kurumlarında Performansa Dayalı Ek}

\section{Ödeme Sistemi}

\subsection{Performans ve Performans Yönetimi}

Performans kavramıyla ilgili literatürde çok çeşitli tanımlara rastlamak mümkündür. Performans en genel anlamda, 'bir görev çerçevesinde önceden belirlenen ölçütleri karşılayacak biçimde, görevin yerine getirilmesi ve amacın gerçekleştirilmesi yönünde ortaya konan mal, hizmet ya da düşünce", olarak tanımlanır (Helvac1, 2002, s. 156). Sağlık kuruluşları ve çalışan sağlık personeli açısından, Yoluk' a göre ise (2010, s. 4), 'sağlıkta performans kavramı; Sağlık Bakanlığı'nın belirlediği stratejik amaçları gerçekleştirmek üzere yaptıkları işlerin ve buna bağlı işlemlerin nitel ve nicel olarak belirlenerek ölçülmesi ve böylece sağlı kuruluşu ile sağlık çalışanı personelinin 
başarısının ortaya çıkması ve geliştirilmesinin teşvik edilmesi olarak”, tanımlanmaktadır.

Performans yönetimi, ilk kez 1970'lerde kullanılmış, ancak 1980'lerin ilk yarısına kadar somut bir biçimde tanımlanmamıştır. 1990'larda uygulama alanı, hızla yayılmış ve değişik tanımlamalarla literatürde yerini almıştır (Ildır, 2008, s. 103). Tengilimoğlu, Işık ve Akbolat'a (2009, s. 321) göre, performans yönetimi, 'çalışanların görevlerinin gerektirdiği doğrultuda yetkinliklerinin ve belirli konularda kendileri için oluşturulan hedefi gerçekleştirmelerini ölçmek suretiyle verimliliklerini ölçmek ve arttırmak olarak" ifade edilmektedir. Tengilimoğlu, Işık ve Akbolat (2009, s. 321) devamında ise, ' 'performans yönetiminin, bir örgütte insan kaynaklarının, örgüte olan katkıyı arttıracak şekilde, sosyal ve etik ilkelere de uyularak yönetilmesi'" olarak açıklamaktadır. Performans yönetimi aynı zamanda "örgütü istenen amaçlara yöneltme amaciyla örgütün mevcut ve geleceğe ilişkin durumları ile ilgili bilgi toplama, bunları karşılaştırma ve performansın sürekli gelişimini sağlayacak yeni ve gerekli düzenlemeleri ve etkinlikleri başlatma ve sürdürme görevlerini yüklenen bir yönetim sürecidir'' (Akal, 2000, s. 50).

\subsection{Sağlık Bakanlığı'nda Performansa Dayalı Ek Ödeme Sistemi}

2003 Yılından itibaren önemli bir sağlık sistemi reformu olan ve sağlık sisteminin yönetimini, verimliliğini ve kalitesini iyileştirmeyi amaçlayan Sağlıkta Dönüşüm Programının önemli bir ayağını oluşturan Performansa Dayalı Ek Ödeme Sistemi (PDEÖS); kamu hastanelerinde açıkça tanımlı sonuçların gerçekleştirilmesi ve maaş dışında alınacak ek ücretlerin belli bir tavana kadar performansa dayalı olarak ödenmesini hedefleyen karmaşık ancak standardize bir süreç olup hem bireysel hem de kurumsal teşviklere dayanmaktadır. Performansa Dayalı Ek Ödeme Sistemi (PDEÖS), yıllar itibariyle yenilenerek ve bazı kriterler koyularak geliştirilmiştir.

01.02.2011 Tarihinden itibaren ise Sağlık Bakanlığı'na bağlı hastanelerde uygulanan PDEÖS'e çok benzer bir ek ödeme sistemi üniversite hastanelerinde de uygulanmaya başlanmıştır (Akpınar ve Taş, 2013, s. 171).

\subsection{Performansa Dayalı Ek Ödeme Sisteminin İşleyişi}

PDEÖS'nin temelini oluşturan, 209 Sayılı Sağlık ve Sosyal Yardım Bakanlığı'na Bağlı Sağlık Kurumları ile Esenlendirme (Rehabilitasyon) Tesislerine Verilecek Döner Sermaye Hakkında Kanunu'nun 2. maddesine göre döner sermaye gelirleri, hastanede çalışan personelin faaliyetleri sonucunda elde edilen gelirlerdir. Sistemin ana unsuru sağlık kurumlarında yapılmakta olan 5120 tıbbi işlemin bağıl değerlerinin belirlenerek, puanlandırılmasıdır. Hekimler tarafından bire bir yapılan ve bizzat sonuçlandırılan işlemler puanlandırılmaktadır. Hekim kontrolünde olsa da cihaz ve yardımcı sağlık personeli tarafından yapılan enjeksiyon gibi işlemler puanlandırılmamaktadır (Erkan, 2011, s. 428). Yapılan bu işlemlerin her birinin ücretlendirmesi, Sağlık Uygulama Tebliğgi'nde (SUT) ilan edilen fiyatları üzerinden yapılmaktadır ve SGK tarafindan hastanelere ödenmektedir. Ülkemizde artan sağlık harcamalarını kontrol altında tutabilmek ve sağlık hizmeti maliyetlerini azaltabilmek için yapılan uygulamalardan bir tanesi Paket İşlem Fiyat (PİF) uygulamasıdır. PİF hem özel hem de kamu sağlık işletmelerinde uygulanmaktadır (Özsel, 2015, s. 157).

Sağlık Bakanlığı'nca döner sermayeyle ilgili çeşitli yönetmelikler ve genelgeler yayınlanmaktadır. 2012/24 No'lu genelgeyle tabip diş1 personele, Temmuz 2012 
tarihinden itibaren sabit ek ödeme yapılmaya başlanmıştır.Bu genelge ve 375 Sayılı Kanun Hükmünde Kararname ile hesaplanacak ek ödeme miktarı, belirleyici olmaktadır. Sağlık Bakanlığı'nca döner sermaye ödemelerinin kamu hastanelerinde çalışanlara ilişkin olan kısmı ile ilgili olarak yayınlanan bir diğer yönetmelikte, 14.02.2013 Tarihli, 28559 Sayılı Resmi Gazete'de yayınlanan 'Sağlık Bakanlığı Türkiye Kamu Hastaneleri Kurumu'na Bağlı Sağlık Tesislerinde Görevli Personele Ek Ödeme Yapılmasına Dair Yönetmelik', tir. Bu yönetmeliğe göre, hastanelerde çalışan personele ek ödeme tutarının belirlenmesi için, Kamu Hastaneleri Birliği Genel Sekreterliği'ne bağlı her hastanede, hastane yöneticisinin sorumluluğunda, her yıl döner sermaye komisyonu ve tabiplerce gerçekleştirilen tabip muayene ve girişimsel işlemleri incelemek amaciyla da birliğe bağlı her bir sağlık tesisinde inceleme heyeti oluşturulmaktadır.

Sözkonusu yönetmeliğin 5. maddesinin 3. fikrasında, dağıtılacak ek ödemenin üst sınırıda belirlenmiştir. 'Türkiye Kamu Hastaneleri Kurumu'na bağlı ikinci ve üçüncü basamak sağlık tesislerinin bağış, faiz ve kira gelirleri, ek ödeme dağıtımında kullanılamaz ve bu birimlerde görevli personele yapılacak ek ödeme toplamı, ilgili birimin cari yıldaki hizmet bedelinden ayrı olarak faturalandırılan ilaç ve her türlü tıbbi sarf malzemesi gelirlerinin yüzde kırk beşini, diğer döner sermaye gelirlerinin ise yüzde ellisini aşamaz. Türkiye Kamu Hastaneleri Kurumu, bu fikrada öngörülen oranları kamu hastane birlikleri bazında hesaplamaya da yetkilidir; ancak bu hâlde dahi yüzde elli oranı, her bir sağlık tesisi bazında yüzde altmış beşi geçemez.',

Aynı yönetmeliğin 8 . maddesi 1. bendine göre, döner sermaye komisyonu, dağıtılacak tutarı (karar alınan tutar), sağlık tesisinin o dönemde elde ettiği gayrisafi hasılattan, öncelikle Hazine payı, 24/5/1983 tarihli ve 2828 sayılı Sosyal Hizmetler Kanununun 18 inci maddesinin birinci fikrasının $(\mathrm{k})$ bendi gereğince ayrılacak pay ile Bakanlık merkez payı ayrıldıktan sonra kalan miktarın, 209 sayılı Kanunun 5 inci maddesinin üçüncü fikrasında belirlenen oranın, sağlık tesisi kalite katsayısı ile çarpımı sonucu bulunan miktarı geçmeyecek şekilde belirler. Sağlık tesisi döner sermaye komisyonunca belirlenen dağıtılacak ek ödeme tutarı, genel sekreterin onayıla kesinleşir.

SB. Türkiye Kamu Hastaneleri Kurumuna Bağlı Sağlık Tesislerinde Görevli Personele Ek Ödeme Yapılmasına Dair Yönetmeliğin 4. maddesinin çç fikrasında geçen sağlık tesisi kalite katsayısı, dağıtılacak ek ödeme tutarının belirlenmesinde önem taşımaktadır. Sağlık tesisi katsayısı, hastanede görev yapan çalışanların, döner sermayeden dağıtılacak ek ödeme tutarının belirlenmesi amacıyla hesaplanmaktadır. Hesaplamada kullanılan kriterler, hasta ve çalışan memnuniyeti kriterleri ile sağlık hizmeti kalite standartları kriterleridir. Sağlık Hizmetleri Genel Müdürlügü tarafından çıkarılan 'Memnuniyet Anketleri Uygulama Rehberine"' (Temmuz 2015, s. 9) göre, hastane yatak sayıları baz alınarak; ayaktan hasta memnuniyet anketi, yatan hasta memnuniyet anketi, acil servis hasta memnuniyet anketi, çalışan memnuniyet anketi yapılmaktadır. Çalışan memnuniyet anketi, yılda iki kez, Mart ve Eylül aylarında uygulanırken, hasta anketleri her ay uygulanmaktadır. Yapılan anketler sonucunda, memnuniyet katsayısı tespit edilmektedir.

Sağlık hizmeti kalite standart kriterleri ise hastanelerin alt yapısını, komite çalışmalarını, hasta bakımı, otelcilik hizmetleri gibi hastanenin tüm süreçlerini kapsayan 
kriterlerdir. Bu kriterler, hasta ve çalışan güvenliğini sağlaması yönünden de oldukça önemlidir (Çakır, 2014, s.126).

Sözkonusu yönetmelikte, ikinci ve üçüncü basamak sağlık tesislerinde net performans puanının hesaplanması da açıklanmıştır.

\section{Üçüncü basamak săglık tesislerinde net performans puanının hesaplanması}

Aynı yönetmeliğin 10. maddesi 1. bendine göre, mesai içi çalışan (mesai saatleri içinde yapılan çalışmalar ile nöbet ve icap nöbetlerinde yapılan çalışmalar) personelin net performans puanları aşağıdaki şekilde hesaplanır:

a) Bir kliniğe bağlı olarak çalışanlar:

1) Eğitim sorumlusu, eğitim görevlisi, başasistan ve uzman tabipler, acil kliniklerde ise pratisyen tabipler: Net performans puan $1=[(($ Klinik hizmet puan ortalamas1 x 0,75$)+$ (Mesai içi sağlık tesisi puan ortalaması x 0,25)) x Hizmet alanı-kadro unvan katsayısı x Mesai içi aktif çalışılan gün katsayısı $]+$ Bilimsel çalışma destek puanı + [(Tabip muayene ve girişimsel işlemler puanı - (Klinik hizmet puan ortalaması x Mesai içi aktif çalışılan gün katsayısı)) x 0,5] + (Ek puan x Mesai içi aktif çalışılan gün katsayısı).

2) Asistanlar: Net performans puan $1=[(($ Klinik hizmet puan ortalaması $x \quad 0,25)+$ (Mesai içi sağlık tesisi puan ortalaması x 0,75)) x Hizmet alanı-kadro unvan katsayısı x Mesai içi aktif çalışılan gün katsayısı] + Bilimsel çalışma destek puanı $+($ Ek puan $x$ Mesai içi aktif çalışılan gün katsayısı).

3) Yan dal asistanları: Net performans puan1 $=[($ Klinik hizmet puan ortalamas $1 \times 0,60)$ + (Mesai içi sağlık tesisi puan ortalaması x 0,40)) x Hizmet alanı- kadro-unvan katsayısı $\mathrm{x}$ Mesai içi aktif çalışılan gün katsayısı] + Bilimsel çalışma destek puanı $+($ Ek puan $\mathrm{x}$ Mesai içi aktif çalışılan gün katsayısı).

b) Bir kliniğe bağlı olarak çalışmayanlar:

1) Tabip muayene ve girişimsel işlemler puanı bulunan uzman tabip, tabip, uzman diş tabibi ve diş tabipleri: Net performans puanı $=($ Mesai içi sağlık tesisi puan ortalaması $\mathrm{x}$ Hizmet alanı-kadro unvan katsayısı x Mesai içi aktif çalışılan gün katsayısı) + [(Tabip muayene ve girişimsel işlem puanı - (Mesai içi sağlık tesisi puan ortalaması x Mesai içi aktif çalışılan gün katsayısı)) x 0,5] + Bilimsel çalışma destek puanı + (Ek puan x Mesai içi aktif çalışılan gün katsayısı).

c) Diğer personel (tabip dışı personel): Net performans puanı $=($ Mesai içi sağlık tesisi puan ortalaması x Hizmet alanı-kadro unvan katsayısı x Mesai içi aktif çalışılan gün 
katsayısı) + Bilimsel çalışma destek puanı + (Ek puan x Mesai içi aktif çalışılan gün katsayis1).

Sözkonusu yönetmeliğin 10. maddesi 2. bendinde ise, mesai dışı çalışan (mesai saatleri içinde yapılan çalışmalar ile nöbet ve icap nöbetlerinde yapılan çalışmalar hariç, sınırları Hastane Yöneticisi tarafından belirlenen çalışma günlerinde yapılan çalışmalar) personelin net performans puanlarının hesaplanması yer almaktadır.

Yönetmeliğe göre, "hizmet alanı-kadro unvan katsayısı"; uzman tabip kadrosuna atanan profesör ve doçentler için (8), uzman tabipler için (7), pratisyen tabip ve diş tabipleri için (5), eczacılar için $(2,5)$, ameliyathane, yoğun bakım, diyaliz, yenidoğan ünitesi gibi özellikli birimlerde çalışanlar için (2) ve bunların dışında kalan personel için $(1,5)$ olarak hesaplanır.

Sözkonusu yönetmeliğin 11. maddesi 1 . bendine göre, personele ait mesai içi net performans puanının mesai içi dönem ek ödeme katsayısı ile çarpımı sonucu brüt ek ödeme tutarı bulunur. Bu tutar mesai içi tavan ek ödeme tutarını geçemez. Tavan ek ödeme tutarını aşmayacak şekilde belirlenen mesai içi brüt ek ödeme tutarı varsa birim performans katsayısı ile çarpılır ve bu tutardan gelir vergisi ve damga vergisi düşülerek ödenecek net ek ödeme tutarı bulunur. 2. Bendine göre, mesai dışı ödenecek brüt ek ödeme tutarı, mesai dışı net performans puanının mesai dışı dönem ek ödeme katsayısı ile çarpımı sonucu bulunur. Bu tutar mesai dışı tavan ek ödeme tutarını geçemez. Tavan ek ödeme tutarını aşmayacak şekilde belirlenen mesai dışı brüt ek ödeme tutarından gelir vergisi ve damga vergisi düşülerek ödenecek net ek ödeme tutarı bulunur.Ek ödeme, aylık dönemler halinde yapılır. Dağıtılmasına karar verilen ek ödeme tutarı, o dönemin bitiminden sonraki yirmi gün içinde hak sahiplerine ödenir. Ancak, döner sermaye gelirlerinin tahsilatında gecikme olması halinde tahsilatı takip eden ilk ödeme döneminde ödeme yapılır.

\subsection{Performansa Dayalı Ek Ödeme Sistemi’nin Güçlü ve Zayıf Yönleri}

2003 yılının başında Sağlıkta Dönüşüm Programı'nın hayata geçirilmesiyle önem kazanan PDEÖS'ün sağlıklı bir şekilde uygulanması, adil, rasyonel ve objektif bir biçimde ölçülmesine bağlıdır. Erkan'a (2011, s. 435) göre, '’performans yönetiminde yapılacak bir hata (örneğin değerleme sistemlerinden veya değerleyicilerden kaynaklanan), sistemin güven ve motivasyon üzerine dayanan temel dinamiklerini olumsuz yönde etkileyecektir." Bu nedenle sistemin işleyişi kadar denetimi de önem kazanmaktadır.

Sağlıkta performansa dayalı döner sermaye uygulamasına ilişkin yapılan olumlu yorumları değerlendirdiğimizde; sistemin uygulanmasının sonuçları (Erkan, 2011, s. 435) şu şekilde özetlenmektedir:

- Performans değerlendirme sistemi, personel verimliliğini sağlayarak, artan sağlık hizmet talebinin karşılanmasındaki en önemli araç olmuştur.

- Performans değerlendirme sistemi, hastanelerin mevcut kapasitelerini daha verimli kullanmalarını sağlamıştır.

- Sistem sayesinde hekimlerin kamuda tam zamanlı çalışma konusunda önceki dönemlere göre daha istekli hale geldikleri görülmüştür. 2002 yılında \% 11 olan kamuda tam zamanlı çalışan uzman hekim oranı, 2007 yılında \% 62 olmuştur. 
- Bir üst kuruma sevk oranları düşmüş, hastaların kendi yerleşim bölgelerinde tedavi oranları artmıştır.

- Poliklinik oda sayısında belirgin bir artış meydana gelmiştir.

Sağlıkta, performansa dayalı döner sermaye uygulamasına ilişkin yapılan olumsuz değerlendirmeler ise şu şekilde özetlenmektedir:

- Çalışanların faaliyetleri sonucunda elde edilen döner sermaye gelirlerinin bir kısmı hastanenin ihtiyaçları için kullanılmakta, bir kısmı ise çalışanlara ek ödeme olarak dağıtılmaktadır. Her hastane kendi kazandığı döner sermaye geliri ölçüsünde çalışanlarına ek ödeme dağıtabilmektedir. Değişik hastanelerde hekimlerin elde ettiği aynı puanlara karşılık aynı tutarda ödeme yapılmalıdır. Hastanelerin elde ettiği kazanç, hastanenin bulunduğu yer, nüfus, hekim sayısı, fiziki ve tıbbi donanımı gibi unsurlara bağlı olduğu için, döner sermaye kazançları her hastanede farklılık gösterebilmektedir. Bu nedenle, farklı hastanelerde çalışan hekimler, aynı puana sahip olsalar dahi farklı ek ödeme alabilmektedir (Çakır, 2014, s. 132).

- Sağlık Bakanlığı hastanelerinde uygulanmaya başlayan kurumsal ve bireysel performans sistemi, döner sermaye gelirlerinin bölüşümünde istismara yol açacak niteliktedir ve personel arasında çatışmalara neden olmaktadır. Bu sistemin bilimsel performans değerlendirme kriterlerine uygun olarak geliştirilmesi gerekmektedir.

- Doktorların daha fazla performans puanı toplayabilmek için, hastalara daha az zaman ayırarak daha fazla hastaya bakma eğilimleri ortaya çıkmaktadır. $\mathrm{Bu}$ durumun hizmetin kalitesinin düşmesine yol açabileceği endişeleri mevcuttur.

- Döner sermaye uygulaması ile birlikte sağlıkta özelleştirmenin adımları atılmış, "müşteri” odaklı anlayışın uygulanmak istenmesi, sağlığı temel bir insan hakkı olmaktan çıkardığı gibi kamu kuruluşlarında hasta-sağlık emekçisi arasına para kavramının girmesine neden olmuştur. Bu şekilde sağlık hizmetini sunan sağlık emekçileri ile sağlık hizmetini alan halk karşı karşıya getirilmek istenmiştir (Bolat, 2012, s. 56-57).

- Sisteme getirilen eleştirilerden en önemlilerinden biri de hasta sayısı, yatak işgal oranı ve yatak devir hızlarında artış görülürken ortalama kalış gün süresinin kısalmasıdır. Sistem ekip çalışması yerine hekim odaklı bir sistemi teşvik etmektedir. Hekim ne kadar çok hasta bakar, ne kadar çok ameliyat yaparsa o kadar çok performans puanı toplamakta ve o kadar yüksek ücret almaktadır. Ancak bütün bunların doğal bir sonucu olarak hekimin hastaya ayırdığı süre kısalmaktadır. Aynı zamanda eğitim ve araştırma misyonu yüklenen üçüncü basamak hastanelerde durum daha da kötü sonuçlara yol açabilmektedir. Sistemin mali yönüne odaklanılması nedeniyle bu hastaneler asistanların yetiştirilmesi ve akademik çalışmalar yapılması gibi asli görevlerine daha az vakit ayırabilmektedirler (Çakır ve Sakoğlu, 2014, s. 6).

\subsection{Sağlıkta Tam Gün Kanunu}

21.01.2010 tarihli 5947 Sayılı Tam Gün Kanunu, üniversitede çalışan öğretim üyeleriyle, kamuda çalışan hekimlerin, özel bir sağlık kuruluşunda ya da kendilerine ait özel muayenehanelerinde çalışamayacaklarıyla ve kamuyu tercih etmeleri taktirde, ek ödemelerinde yapılacak iyileştirmeyle ilişkilidir.5947 Sayılı Tam Gün Kanunu'nda zamanla değişiklikler yapılmıştır. Tam Gün Kanunu'nun kabulünden sonra Anayasa 
Mahkemesi, 04.12.2010 tarihli ve 27775 Sayılı Resmi Gazete'de yayınlanan kararla, üniversite hocalarının özelde çalışmasıyla ilgili engeli ortadan kaldırmış ancak kamuda çalışan hekimlerin mesai sonrası özel bir yerde çalışmaları önündeki yasak aynen devam etmiştir. Anayasa Mahkemesi'nin aldığ Bakanlar Kurulu Kararı ile çıkartılan 650 Sayılı Kanun Hükmünde Kararname'nin 38. maddesi, memurların ek bir işte çalışamayacaklarıyla ilgilidir. Bu gelişmelerden sonra yaşanan bir diğer gelişme Anayasa Mahkemesinin, KHK'nın devlet, üniversite hastaneleri, TSK, GATA gibi değişik kurumlarda çalışan hekimlere çalışma yasakları getiren maddelerini "yetki kanunu kapsamına girmediğinden" iptal etmesidir. Anayasa Mahkemesi, iptal kararının uygulamaya gireceği tarihi 1 Temmuz 2013 yılına kadar ertelemiştir. Bütün bu yasal süreçler sonucunda, 5947 Sayılı Tam Gün Kanunu'nda yeni bir düzenleme yapılması gerekirken, mevcut hükümet, 1 Temmuz 2013 tarihine kadar yeni bir yasal düzenleme yapmamıştır. Bunun sonucunda üniversitelerde öğretim üyesi olarak çalışan hocaların özel muayehanelerinde çalışmaları önünde bir engel kalmamıştır.

1 Temmuz 2013'e kadar Tam Gün Kanunu'nda yapılması beklenen düzenleme, ancak 2 Ocak 2014 tarihinde, TBMM'de kabul edilen 6514 sayılı kanunla yapılabilmiştir. Bu kanunla, kamu hastaneleri, TSK hastaneleri, üniversite hastaneleri sözleşmeli öğretim üyesi istihdam edebilecektir. Kamu hastanelerine sözleşmeli olarak geçecek öğretim üyelerinin tüm özlük ve akademik ünvanları, üniversite de çalışıyormuş gibi devam edecektir. Bununla beraber profesör ve doçentler, toplam sayılarının \%50'sini geçmemek şartıyla mesai saatleri dişında özel hastane ve vakıf hastanelerinde kurum sözleşmesi yaparak çalışabileceklerdir. 6514 Sayılı kanunun çıkarılması üzerine, Anayasa Mahkemesi'ne kanunun yürürlüğünün durdurulması için başvurulmuş ve Anayasa Mahkemesi de bu kanunun bazı maddelerinin yürürlüğünü, Anayasaya aykırılığı konusunda güçlü belirtiler bularak durdurmuştur.

Sonuç olarak, yürürlüğün durdurulması kararıyla, Sağlık Bakanlığı hastanelerinde çalışan hekimler ve üniversitede çalışıp da muayenehanesi bulunmayan öğretim üyeleri için yeni bir durum sözkonusu olmamaktadır. Yani bu statülerde bulunan hekimler için serbest çalışma yasağı yasadaki gibi devam etmektedir.

\section{Uygulama}

\subsection{Araştırmanın Amacı}

Araştırmanın amac1, 21.01.2010 tarihinde kabul edilen ve Tam Gün Kanunu olarak bilinen, 5947 sayılı "Üniversite ve Sağlık Personelinin Tam Gün Çalışmasına ve Bazı Kanunlarda Değişiklik Yapılmasına Dair Kanunu'nun”, SB. Dışkapı Yıldırım Beyazıt Eğitim ve Araştırma Hastanesi'nin 2009-2015 yıllarına ait ek ödeme tutarları ve toplam maliyetler üzerindeki etkisini incelemektir. Tam Gün Kanunu'nun kabulünden sonra, hastanenin ek ödeme tutarlarındaki değişim ve bu değişimin maliyetlere olan etkisi, araştırmanın amacını oluşturmaktadır.

Tam Gün Kanunu'yla hekimlerin muayehanelerini kapatması ve tam gün kamu da çalışması teşvik edilmektedir. Bu anlamda, hastanelerin hekimlere ödeyeceği ek ödeme tutarları da önem taşımaktadır.

Araştırmada, Ankara ilindeki SB. Dışkapı Yıldırım Beyazıt Eğitim ve Araştırma Hastanesi'nden tarafımızca elde edilen mali veriler incelenmiş ve karşılaştırılmıştır. 


\subsection{Araştırmanın Sınırlılıkları}

$\mathrm{Bu}$ çalışmanın Ankara ilindeki SB. Dışkapı Yıldırım Beyazıt Eğitim ve Araştırma Hastanesi'nde yapılmış olması ve araştırmanın 2009 yılı ve sonrası verilerini içermesi araştırmanın sınırlılığını oluşturmaktadır.

\subsection{Araştırmanın Yöntemi}

Araştırma verileri sözkonusu hastaneden gerekli izinler alınarak elde edilmiştir. Tarafımızca sağlanan mali veriler karşılaştırılmış ve baz yıla göre değişim yorumlanmıştır. Sözkonusu karşılaştırmada, 2009-2015 yıllarına ait döner sermaye ve toplam maliyet tutarları, Yİ-ÜFE'ye göre düzeltilmiştir. Düzeltme, 2015 yılının para değerine göre yapılmıştır. Düzeltilmiş ek ödeme tutarları ve toplam maliyet tutarları da eğilim yüzdeleri yöntemi (trend analizi) ile analiz edilmiştir. Trend analizinde baz y1l olarak 2009 ele alınmıştır.

2009 yılının baz yıl olarak ele alınmasının sebebi, 2010 yılında, 5947 Sayılı Tam Gün Kanunu'nda yapılan değişiklikten önceki bir yıl olması ve daha önceki yıllara ait veri bulunamamasidir.

\subsection{Araştırmada Kullanılan Veri Seti ve Kapsamı}

Araştırmada, SB. Ankara Dışkapı Yıldırım Beyazıt Eğitim ve Araştırma Hastanesi'nin mali verileri kulanılmıştır. Analizde kullanılmış olan hastanenin yıllar itibariyle (2009 ve 2015 yılı dahil) mali verileri şunlardır:

- SB. Dışkapı Yıldırım Beyazıt Eğitim ve Araştırma Hastanesi’nin 2009 Yı1ı Giderler Döküm Cetveli,

- SB. Dışkapı Yıldırım Beyazıt Eğitim ve Araştırma Hastanesi’nin 2010 Yı1ı Giderler Döküm Cetveli,

- SB. Dışkapı Yıldırım Beyazıt Eğitim ve Araştırma Hastanesi’nin 2011 Yı1ı Giderler Döküm Cetveli,

- SB. Dışkapı Yıldırım Beyazıt Eğitim ve Araştırma Hastanesi’nin 2012 Y11 Gider/Gelir Gerçekleştirme Raporu (Detaylı),

- SB. Dışkapı Yıldırım Beyazıt Eğitim ve Araştırma Hastanesi’nin 2013 Yı1ı Gider/Gelir Gerçekleştirme Raporu (Detaylı),

- SB. Dışkapı Yıldırım Beyazıt Eğitim ve Araştırma Hastanesi’nin 2014 Yı1ı Bütçe Gerçekleşmeleri,

- SB. Dışkapı Yıldırım Beyazıt Eğitim ve Araştırma Hastanesi’nin 2015 Yı1ı Bütçe Gerçekleşmeleri,

\subsection{Araştırmanın Bulguları}

Araştırmada, SB. Ankara Dışkapı Yıldırım Beyazıt Eğitim ve Araştırma Hastanesi'nin mali verileri (2009 ve 2015 yılı dahil) kulanılmıştır.

Araştırmada, SB. Ankara Dışkapı Yıldırım Beyazıt Eğitim ve Araştırma Hastanesi'nin 2009 yılından 2015 yılına (2009 ve 2015 yılı da dahil olmak üzere) kadar gerçekleşmiş ek ödeme tutarları Tablo 2'de görülmektedir. Ek ödeme tutarları, giderler döküm cetvelinden, detaylı gider/gelir gerçekleştirme raporundan ve bütçe gerçekleşmeleri raporundan alınmıştır. 
2009, 2010, 2011 yıllarında ödenen ek ödeme tutarları, giderler döküm cetvelindeki '"770.05', hesap kodlu ''Ek Çalışma Karşılıkları', adlı hesapta izlenmektedir.

2012 ve 2013 yıllarında ödenen ek ödeme tutarları, detaylı gider/gelir gerçekleştirme raporunun ' Toplam Personel Gideri' ' bölümünde, ' 34 .Ek Ödeme'” adlı hesapta izlenmektedir. 2014 ve 2015 yıllarında ödenen ek ödeme tutarları ise bütçe gerçekleşmeleri raporunun 'Toplam Gerçekleşen Ek Ödeme Giderleri'” bölümünde izlenmektedir.

\section{Ek Ödeme Tutarları}

Tablo 2: Ankara Dışkapı Yııldırım Beyazıt Eğitim ve Araştırma Hastanesi’nin 2009-2015 Yıllarına Ait Gerçekleșen Ek Ödeme Tutarları

\begin{tabular}{cc}
\hline YILLAR & EK ÖDEME TUTARLARI \\
2009 & 45.335 .952 .74 \\
2010 & 48.790 .086 .49 \\
2011 & 48.984 .308 .45 \\
2012 & 55.285 .261 .77 \\
2013 & 61.923 .845 .80 \\
2014 & 70.346 .054 .00 \\
2015 & 75.538 .795 .00 \\
TOPLAM & 406.204 .304 .25 \\
\hline
\end{tabular}

Tablo 2 incelendiğinde, 2009-2015 y1larına ait gerçekleşen ek ödeme tutarlarında, yıllar itibariyle artış olduğu görülmektedir. 21.01.2010 Tarihinde kabul edilen 5947 Sayılı Tam Gün Kanunu'ndan sonra sözkonusu ek ödeme tutarlarında artış olduğu görülmektedir.

\begin{tabular}{|c|c|c|c|}
\hline \multicolumn{4}{|c|}{$\begin{array}{l}\text { Toplam Maliyet Tutarları ve Ek Ödeme Tutarlarının Toplam Maliyet Tutarları } \\
\text { İçindeki Oranı } \\
\text { Tablo 3: Ankara Dışkapı Yıldırım Beyazıt Eğitim ve Araştırma Hastanesi’nin } \\
\text { 2009-2015 Yıllarına Ait Ek Ödeme Tutarlarının Toplam Maliyet } \\
\text { Tutarları İçindeki Oranı } \\
\end{array}$} \\
\hline \multirow[t]{2}{*}{ YILLAR } & EK ÖDEME & $\begin{array}{c}\text { TOPLAM } \\
\text { MALIYET }\end{array}$ & $\begin{array}{l}\text { TOPLAM MALIYYTE } \\
\text { GÖRE DİKEY }\end{array}$ \\
\hline & TUTARLARI & TUTARLARI & YÜZDELER \\
\hline 2009 & $45.335 .952,74$ & $153.460 .955,28$ & $\% 29.54$ \\
\hline 2010 & $48.790 .086,49$ & $144.451 .818,02$ & $\% 33.77$ \\
\hline 2011 & $48.984 .308,45$ & $155.745 .781,50$ & $\% 31.45$ \\
\hline 2012 & $55.285 .261,77$ & $161.396 .487,51$ & $\% 34.25$ \\
\hline 2013 & $61.923 .845,80$ & $180.679 .670,27$ & $\% 34.27$ \\
\hline 2014 & $70.346 .054,00$ & $203.137 .455,00$ & $\% 34.62$ \\
\hline 2015 & $75.538 .795,00$ & $213.127 .129,00$ & $\% 35.44$ \\
\hline
\end{tabular}


Tablo 3'te de görüldüğü gibi ek ödeme tutarları artmıştır. Toplam maliyet tutarları da 2010 yılı hariç artmıştır. Ek ödeme tutarlarının toplam maliyetler içindeki oranı da 2011 yılı hariç artmıştır.

\section{Ek Ödeme Tutarlarının Yİ-ÜFE' ye Göre Analizi}

Ek ödeme tutarlarının karşılaştırılması için önceki dönem verilerinin cari dönem para değerine göre (2015) düzeltilmesi, böylece aynı satın alma gücüne göre ifade edilmiş verilerin eğilim yüzdelerinin saptanması daha anlamlı sonuçlar doğurabilmektedir. Bunun için düzeltmede kullanılan endeks, Yurt İçi Üretici Fiyat Endeksidir (Yİ-ÜFE) ${ }^{2}$

Düzeltmede kullanılan Yurt İçi Üretici Fiyat Endeksi düzeltme katsayıları, aşağıdaki gibidir. Düzeltme, 2015 yılının parasına göre yapılmıştır.

\section{Endeksler}

2009 Aralik 163,98

2010 Aralık 178,54

2011 Aralık 202,33

2012 Aralik 207,29

2013 Aralik 221,74

2014 Aralık 235,84

2015 Aralık 249,31

\section{Katsayılar}

2009 için $249,31 / 163,98=1,5203$

2010 için $249,31 / 178,54=1,3963$

2011 için $249,31 / 202,33=1,2321$

2012 için $249,31 / 207,29=1,2027$

2013 için $249,31 / 221,74=1,1243$

2014 için $249,31 / 235,84=1,0571$

2015 için $249,31 / 249,31=1$

Her yılın ek ödeme tutarları, kendi yılının katsayısı ile çarpılarak 2015 yılının para değerine getirilmiştir.

$$
\begin{aligned}
& 2009 \text { için } 45.335 .952,74 \times 1,5203=68.924 .248,95 \\
& 2010 \text { için } 48.790 .086,49 \times 1,3963=68.125 .597,76 \\
& 2011 \text { için } 48.984 .308,45 \times 1,2321=60.353 .566,44 \\
& 2012 \text { için } 55.285 .261,77 \times 1,2027=66.491 .584,33 \\
& 2013 \text { için } 61.923 .845,80 \times 1,1243=69.620 .979,83 \\
& 2014 \text { için } 70.346 .054,00 \times 1,0571=74.362 .813,68 \\
& 2015 \text { için } 75.538 .795,00 \times 1=75.538 .795,00
\end{aligned}
$$

\footnotetext{
2 Türkiye İstatistik Kurumu (TÜİK) tarafından yayınlanan Toptan Eşya Fiyat Endeksi (TEFE), 2014 Ocak ayından itibaren yayınlanmamaktadır. 2014 yılından itibaren TEFE endeksleri yerine, Yurt İçi Üretici Fiyat Endeksi (Yİ-ÜFE) kullanılmaya başlanmıştır(İnternet: http://www.tuik.gov.tr adresinden 24 Haziran 2016 tarihinde alınmıştır).
} 
Tablo 4 incelendiğinde, Yurt İçi Üretici Fiyat Endeksi'ne (Yİ-ÜFE) göre düzeltilmiş ek ödeme tutarları, 2009 yılına göre, 2010, 2011 ve 2012 yıllarında düşmüş, 2013, 2014 ve 2015 yıllarında ise artmıştır.

Tablo 4: Ankara DışkapıYıldırım Beyazıt Eğitim ve Araştırma Hastanesi’nin 2009-2015 Yıllarına Ait Ek Ödeme Tutarları ve Yi-üfe'ye Göre Düzeltilmiş Ek Ödeme Tutarları

\begin{tabular}{ccc}
\hline YILLAR & $\begin{array}{c}\text { EK ÖDEME } \\
\text { TUTARLARI }\end{array}$ & $\begin{array}{c}\text { YİÜ̈Ë'YE } \\
\text { GÖREDÜZELTİLMİs EK } \\
\text { ÖDEME TUTARLARI }\end{array}$ \\
2009 & $45.335 .952,74$ & $68.924 .248,95$ \\
2010 & $48.790 .086,49$ & $68.125 .597,76$ \\
2011 & $48.984 .308,45$ & $60.353 .566,44$ \\
2012 & $55.285 .261,77$ & $66.491 .584,33$ \\
2013 & $61.923 .845,80$ & $69.620 .979,83$ \\
2014 & $70.346 .054,00$ & $74.362 .813,68$ \\
2015 & $75.538 .795,00$ & 75.538 .795 .00 \\
\hline
\end{tabular}

\section{Toplam MaliyetTutarlarının Yi-üfeye Göre Analizi}

Toplam maliyet tutarlarının karşılaştırılması için önceki dönem verilerinin cari dönem para değerine göre (2015) düzeltilmesi, böylece aynı satın alma gücüne göre ifade edilmiş verilerin eğilim yüzdelerinin saptanması enflasyon dönemlerinde daha anlamlı sonuçlar doğurabilmektedir. Bunun için düzeltmede kullanılan endeks, Yurt İçi Üretici Fiyat Endeksidir (Yİ-ÜFE).

Her yılın toplam maliyet tutarları, kendi yılının katsayısı ile çarpılarak 2015 yılının para değerine getirilmiştir.

2009 için $153.460 .955,28 \times 1.5203=233.306 .690,31$

2010 için $144.451 .818,02 \times 1.3963=201.698 .073,50$

2011 için $155.745 .781,50 \times 1.2321=191.894 .377,38$

2012 için $161.396 .487,51 \times 1.2027=194.111 .555,52$

2013 için $180.679 .670,27 \times 1.1243=203.138 .153,28$

2014 için $203.137 .455,00 \times 1.0571=214.736 .603,68$

2015 için $213.127 .129,00 \times 1=213.127 .129,00$

Tablo 5 incelendiğinde, Yİ-ÜFE’ye göre düzeltilmiş toplam maliyet tutarları, 2009 yılına göre, 2010, 2011, 2012, 2013, 2014 ve 2015 y1llarında azalma göstermiştir. 
Tablo 5: Ankara Dışkapı Yıldırım Beyazıt Eğitim ve Araştırma Hastanesi'nin 2009-2015 Yıllarına Ait Yi-üfe'ye Göre Düzeltilmiş Toplam Maliyet Tutarları

\begin{tabular}{ccc}
\hline YILLAR & TOPLAM MALIYYT & Yİ-ÜFE'YE GÖRE \\
& TUTARLARI & $\begin{array}{c}\text { DÜZELTİLMIŞ TOPLAM } \\
\text { MALIYYET TUTARLARI }\end{array}$ \\
2009 & 153.460 .955 .28 & $233.306 .690,31$ \\
2010 & 144.451 .818 .02 & $201.698 .073,50$ \\
2011 & 155.745 .781 .50 & $191.894 .377,38$ \\
2012 & 161.396 .487 .51 & $194.111 .555,52$ \\
2013 & 180.679 .670 .27 & $203.138 .153,28$ \\
2014 & 203.137 .455 .00 & $214.736 .603,68$ \\
2015 & 213.127 .129 .00 & 213.127 .129 .00 \\
\hline
\end{tabular}

Yi-üfe’yeGöre Düzeltilmiş Ek Ödeme Tutarlarının ve Yi-üfe'ye Göre Düzeltilmiş Toplam Maliyet Tutarlarının Ĕ̆ilim Yüzdeleri Yöntemi ile Analizi (Trend Analizi)

Trend analizi, finansal tablolarının analizinde kullanılan bir yöntem olup, bir yıl baz yıl olarak kabul edilmekte ve bu yıla ait tutarlar 100 olarak hesaplanmaktadır. Sözkonusu çalışmamızda baz yıl olarak 2009 yılı ele alınmış ve bu yıla ait tutarlar 100 kabul edilmiştir. Yapılan analizde, yıllar itibariyle Yİ-ÜFE'ye göre düzeltilmiş ek ödeme tutarlarının ve Yİ-ÜFE'ye göre düzeltilmiş toplam maliyet tutarlarının göstermiş olduğu artışlar ve azalışlar değerlendirilmiştir.

\section{Yi-üfe'ye Göre Düzeltilmiş Ek Ödeme Tutarlarının Trend Analizine Göre Değerlendirilmesi}

2009 Y1lı temel yıl olarak seçilmiş ve bu yıla ait tüm değerler 100 kabul edilmiştir. 2015 Yılının para değerine göre düzeltilmiş ek ödeme tutarları, temel yıl olarak seçilen 2009 yılının düzeltilmiş ek ödeme tutarına bölünmüş ve bulunan sonuç, 100 ile çarpılmıştır.

2009 için 100
2010 için $68.125 .597,76 / 68.924 .248,95 \times 100=98,84$
2011 için $60.353 .566,44 / 68.924 .248,95 \times 100=87,56$
2012 için $66.491 .584,33 / 68.924 .248,95 \times 100=96,47$
2013 için $69.620 .979,83 / 68.924 .248,95 \times 100=101,01$
2014 için $74.362 .813,68 / 68.924 .248,95 \times 100=107,89$
2015 için $75.538 .795 .00 / 68.924 .248,95 \times 100=109,59$ 
Tablo 6: Ankara Dışkapı Yıldırım Beyazıt Eŭitim ve Araştırma Hastanesi’nin 2009-2015 Yıllarına Ait Yi-üfe'ye Göre Düzeltilmiş Ek

Ödeme Tutarlarının Eğilim Yüzdeleri

\begin{tabular}{cc}
\hline YILLAR & Yİ-ÜFE’YE GÖRE DÜZELTİLMIŞ \\
& EK ÖDEME TUTARLARININ EĞİLİM YÜZDELERİ \\
2009 & 100 \\
2010 & 98,84 \\
2011 & 87,56 \\
2012 & 96,47 \\
2013 & 101,01 \\
2014 & 107,89 \\
2015 & 109,59 \\
\hline
\end{tabular}

Tablo 6 incelendiğinde, düzeltilmiş ek ödeme tutarlarının eğilim yüzdeleri, temel y11 2009' a göre, 2010, 2011 ve 2012 yıllarında azalış, 2013, 2014 ve 2015 yıllarında ise artı̧̧ göstermektedir.

Yi-üfe'ye Göre Düzeltilmiş Toplam Maliyet Tutarlarının Trend Analizine Göre Değerlendirilmesi

2009 Y1lı temel yıl olarak seçilmiş ve bu yıla ait tüm değerler 100 kabul edilmiştir. 2015 Yılının para değerine göre düzeltilmiş toplam maliyet tutarları, temel yıl olarak seçilen 2009 yılının düzeltilmiş toplam maliyet tutarına bölünmüş ve bulunan sonuç, 100 ile çarpılmıştır.

2009 için 100

2010 için $201.698 .073,50 / 233.306 .690,31 \times 100=86,45$

2011 için 191.894.377,38/233.306.690,31x100 = 82,24

2012 için $194.111 .555,52 / 233.306 .690,31 \times 100=83,20$

2013 için 203.138.153,28/233.306.690,31x100 = 87,06

2014 için $214.736 .603,68 / 233.306 .690,31 \times 100=92,04$

2015 için $213.127 .129 .00 / 233.306 .690,31 \times 100=91,35$ 
Tablo 7: Ankara Dışkapı Yıldırım Beyazıt Eğitim ve Araştırma Hastanesi’nin 2009-2015 Yıllarına Ait Yi-üfe'ye Göre Düzeltilmiş Toplam Maliyet Tutarlarının Ĕgilim Yüzdeleri

\begin{tabular}{lc}
\hline YILLAR & Yİ-ÜFE’YE GÖRE DÜZELTILMIŞ̧ \\
& TOPLAM MALIYYET TUTARLARININ EĞİLİM YÜZDELERİ \\
2009 & 100 \\
2010 & 86,45 \\
2011 & 82,24 \\
2012 & 83,20 \\
2013 & 87,06 \\
2014 & 92,04 \\
2015 & 91,35 \\
\hline
\end{tabular}

Tablo 7'ye göre, düzeltilmiş toplam maliyet tutarlarının eğilim yüzdeleri, temel yıl 2009'a göre, 2010, 2011, 2012, 2013, 2014 ve 2015 yıllarında azalış göstermiştir. Düzeltilmiş toplam maliyet tutarlarının eğilim yüzdelerinin, temel yıl 2009'a göre, sürekli bir düşüş eğiliminde olduğu görülmektedir.

Yi-üfe'ye Göre Düzeltilmiş Ek Ödeme Tutarlarının ve Yi-üfe'ye Göre Düzeltilmiş Toplam Maliyet Tutarları Eğilim Yüzdelerinin Karşılaştırılması

Tablo 8: Ankara Dışkapı Yıldırım Beyazıt Eğitim ve Araştırma Hastanesi'nin 2009-2015 Yıllarına Ait Yi-üfe'ye Göre Düzeltilmiş Ek Ödeme Tutarlarının ve Yiüfe'ye Göre Düzeltilmiş Toplam Maliyet

Tutarlarının Eğilim Yüzdeleri

\begin{tabular}{|l|c|c|c|c|c|c|c|}
\hline \multirow{2}{*}{ KALEMLER } & \multicolumn{6}{|c|}{ Yİ-ÜFE'YE GÖRE DÜZELTILMIŞ EĞILİM YÜZDELERİ } \\
\hline YILLAR & $\mathbf{2 0 0 9}$ & $\mathbf{2 0 1 0}$ & $\mathbf{2 0 1 1}$ & $\mathbf{2 0 1 2}$ & $\mathbf{2 0 1 3}$ & $\mathbf{2 0 1 4}$ & $\mathbf{2 0 1 5}$ \\
\hline $\begin{array}{c}\text { EK ÖDEME } \\
\text { TUTARLARI }\end{array}$ & 100 & 98,84 & 87,56 & 96,47 & 101,01 & 107,890 & 109,59 \\
\hline $\begin{array}{c}\text { TOPLAM } \\
\text { MALIYET } \\
\text { TUTARLARI }\end{array}$ & 100 & 86,45 & 82,24 & 83,20 & 87,06 & 92,04 & 91,35 \\
\hline
\end{tabular}

Tablo 8 incelendiğinde, düzeltilmiş ek ödeme tutarlarının eğilim yüzdeleri, temel y11 2009'a, göre 2010,2011 ve 2012'de düşmüş, 2013, 2014 ve 2015 yıllarında ise artış göstermiştir. Yi-üfe'ye göre düzeltilmiş toplam maliyet tutarlarının eğilim yüzdeleri de, temel y1l 2009'a göre, bütün yıllarda sürekli azalış göstermiştir.

Ek ödeme tutarlarını ve toplam maliyet tutarlarını karşılaştırdığımızda her yıl ek ödeme tutarlarının eğilim yüzdesinin, toplam maliyet tutarları eğilim yüzdesinden büyük olduğu görülmüştür. Yani toplam maliyet tutarları eğilim yüzdesi, ek ödeme tutarları eğilim yüzdesinden düşük kalmıştır. 
Halbuki toplam maliyet tutarlarında da ek ödeme tutarlarındaki artış kadar artış beklenmektedir. Toplam maliyet tutarlarındaki artışın beklenildiği kadar olmamasının nedenleri; toplam maliyet içindeki ek ödeme dışında kalan Hizmet Üretim Maliyeti ve Genel Yönetim Giderleri'ne ait diğer kalemler, Diğer Faaliyetlerden Olan Gider ve Zararlar'a ait diğer kalemler ve hastaların hastanedeki ortalama yatış sürelerinin kısa olması düşünülmektedir.

\section{Sonuç ve Öneriler}

2003 yılından itibaren önemli bir sağlık sistemi reformu olan ve sağlık sisteminin yönetimini, verimliliğini ve kalitesini iyileştirmeyi amaçlayan Sağlikta Dönüşüm Programının önemli bir ayağını oluşturan PDEÖS dinamik bir uygulama olup, uygulamanın başladığı günden bu yana sürekli geliştirilmekte ve Sağlık Bakanlığı'nın stratejik hedeflerine göre yenilenmektedir.

Sağlık Bakanlığı'na bağlı tüm sağlık tesislerinde uygulanmakta olan PDEÖS Bakanlıkça belirlenen hizmet sunum şartları ve kriterleri de dikkate alınmak suretiyle, çalışan personelin; unvanı, görevi, çalışma şartları ve süresi, hizmete katkısı, performansı, yapılan muayeneler, ameliyat, anestezi girişimsel işlemler ve özellik arz eden riskli birimlerde çalışma gibi unsurlar esas alınarak sağlık kurumlarında görevli personele döner sermaye gelirlerinden yapılacak ek ödemenin oran, usul ve esaslarının belirlendiği bir sistemdir.

Kamuoyunda, Tam Gün Kanunu olarak bilinen, 5947 sayılı “Üniversite ve Sağlık Personelinin Tam Gün Çalışmasına ve Bazı Kanunlarda Değişiklik Yapılmasına Dair Kanun", 21.01.2010 tarihinde kabul edilmiş, 30.01.2010 tarih ve 27478 sayılı Resmi Gazete'de yayımlanarak yürürlüğe girmiştir. Tam Gün Kanunu hakkında yürütmeyi durdurma kararının alınması, KHK ile yeniden güçlendirilmeye çalışılması, Anayasa Mahkemesi'nin KHK 'nin 27 maddesini iptal etmesi ve 2014 y1lında 6514 Sayılı yeni Tam Gün Kanunu'nun kabul edilmesi bu süreçte yaşanan gelişmelerdir. 21.01.2010 Tarihinde kabul edilen 5947 sayılı Tam Gün Kanunu'nda hekimlerin serbest çalışma izinlerinin kaldırılması ve hekimlerin tam gün hastanede çalışmaya başlaması, hastanelerin ödemiş olduğu ek ödeme tutarlarını da etkilemiştir.

Bu araştırmada, Tam Gün Kanunu'nda 2010 yılında yapılan değişikliklerin ek ödeme tutarlarını ve toplam maliyetleri nasıl etkilediğini incelemek amacıyla, SB. Dışkapı Yıldırım Beyazıt Eğitim ve Araştırma Hastanesi'nin 2009-2015 yıllarına ait ek ödeme tutarları ve toplam maliyetleri trend analizi ile incelenmiştir. Bu incelemede Yiüfe de dikkate alınarak rakamlar fiyat artışlarından arındırılarak değerlendirmeye katılmıştır.

Yapılan analizde, Yi-üfe ‘ye göre düzeltilmemiş ek ödeme tutarlarının her yıl, toplam maliyetlerin de 2010 yılı hariç arttığı görülmüştür. Toplam maliyet içindeki ek ödeme tutarı oranı ise 2011 yılı hariç artmıştır.

Yi-üfe'ye göre yapılan düzeltmeden sonra, ek ödeme tutarlarının temel yıl 2009'a göre, 2010, 2011 ve 2012 yıllarında düştüğü, 2013, 2014 ve 2015 yıllarında ise arttığ1 görülmüştür. Buradaki ek ödeme tutarlarındaki artışın 21.01.2010 tarihinde kabul edilen Tam Gün Kanunu'ndan sonraki yıllarda 2013 yılından itibaren artmaya başlamas1 dikkat çekicidir. Bu artışın nedenleri arasında, 2012 Temmuz ayından itibaren tabip dışı personele, 375 Sayılı KHK ile sabit ek ödeme yapılması, personel sayısının artmas1, 
tabip ve tabip dışı personellerin ek gösterge ve derecelerindeki yükselişinolduğu düşünülmektedir. Toplam maliyetler de 2009 yılına göre her yıl azalmıştır.

Yi-üfe'ye göre yapılan düzeltmeden sonra, her y1l ek ödeme tutarı eğilim yüzdesinin, toplam maliyetlerin eğilim yüzdesinden büyük olduğu görülmüş̧ür. Toplam maliyet tutarındaki artışın beklenildiği kadar olmamasının nedenleri arasında; toplam maliyet içindeki ek ödeme kalemi dışında kalan Hizmet Üretim Maliyeti, Genel Yönetim Giderleri vb, Diğer Faaliyetlerden Olan Gider ve Zararlar'a ait diğer kalemler ve hastaların hastanedeki ortalama yatış sürelerinin kısa olmasından kaynaklandığ düşünülmektedir.

Bu çalışma; PDEÖS'ün, örnek olarak alınan bir hastanede maliyetlere olan etkisi ile sınırlandırılmış bir çalışmadır. Performansa dayalı ek ödeme sisteminin maliyetleri artırması yanında, verimliliği de artırması beklenmektedir. Bu yüzden bu çalışmanın devamı niteliğinde, ek ödeme sisteminin hastanelerin verimliliği üzerindeki etkilerini ölçen çalışmalara da ihtiyaç olduğunu ve böyle çalışmaların da alana katkı sağlayacağı söylenebilir.

Sonuç olarak, PDEÖS'nin bir bütün olarak değerlendirilerek, işleyişteki zayıflıklar ve olumsuzlukların düzeltilmesi, toplumun ve sağlı çalışanlarının memnuniyetini sağlayacak uygulamalarla desteklenmesi gerekmektedir.

\section{Kaynakça}

Akal, Z. (2000). İşletmelerde Performans Ölçüm ve Denetimi, Çok Yönlü Performans Göstergeleri, Milli Prodüktivite MerkeziYayınları No:473, Ankara.

Akpınar, T. A., Taş, Y. (2013).'’Performansa Dayalı Ek Ödeme Sistemine İlişkin Hekimlerin Tutumları Üzerine Kocaeli Üniversitesi Araştırma Ve Uygulama Hastanesi'nde Bir Araştırma', Çalışma ve Toplum Dergisi, Cilt. 2, Sayı: 37, 171.

Bolat, G. (2012). Performansa Dayalı Ücret Sisteminin İşgören Motivasyonuna Etkisi, Atılım Üniversitesi Sosyal Bilimler Enstitüsü, Yayınlanmış Yüksek Lisans Tezi.

Çakır, N. (2014). Performansa Dayalı Ek Ödeme Sisteminin Sağlık Çalışanları Açısından Değerlendirilmesi (Sarayköy Devlet Hastanesi Örneği),Beykent Üniversitesi Sosyal Bilimler Enstitüsü, Yayınlanmış Yüksek Lisans Tezi.

Çakır, Ö., Sakaoğlu, H. H. (2014). 'Sağlık Çalışanlarının Performansa Dayalı Ek Ödeme Sisteminde Ücret Adaleti Algısı: Tepecik Eğitim ve Araştırma Hastanesi Örneği', Çalışma İlişkileri Dergisi, Cilt.5, Sayı: 1, 6.

Erkan, A. (2011). 'Performansa Dayalı Ödeme: Sağl1k Bakanlığı Uygulaması', Maliye Dergisi, Sayı: 160, 435.

Helvac1, A. (2002). 'Performans Yönetimi Sürecinde Performans Değerlendirmenin Önemi’', Ankara Üniversitesi Eğitim Bilimleri Fakültesi Dergisi, Cilt.35, Sayı:1, 156.

http://www.dmisproje.muhasebat.gov.tr., Erişim, 3 Ocak 2016, T.C. Maliye Bakanlığ 1 Muhasebat Genel Müdürlügü Döner Sermaye Mali Yönetim Sistemi.

Kartalcı, K. (2012). 'Döner Sermaye İşletmelerinin Yeniden Yapılandırılması', Akademik Yaklaşımlar Dergisi, Cilt.3, Sayı: 1, 111. 
Kostik, T. (1998). Döner Sermayeli İşletmeler, SeçkinYayınevi, Ankara.

Ildır, A. (2008). Faaliyet Tabanlı Maliyetleme ile Sağlı İşletmelerinde Maliyet Analizi ve Performans Yönetimi, Seçkin Yayıncılık, Ankara.

Özsel, H. (2015). Performansa Dayalı Döner Sermaye Sistemi ve Ofansif Tıp, İzmir Üniversitesi Sosyal Bilimler Enstitüsü, Yayınlanmış Yüksek Lisans Tezi.

Sağlık Hizmetleri Genel Müdürlüğü Sağlıkta Kalite ve Akreditasyon Daire Başkanlığı, (Kasım 2015). Memnuniyet Anketleri Uygulama Rehberi,Mattek Matbaacılık Basım Yayın, Ankara.

Şakrak, M. (1997). Döner Sermaye İşletmelerinde Muhasebe Sistemi, Yasa Yayınları, İstanbul.

Tengilimoğlu, D., Işık, O., Akbolat, M. (2009). Sağlık İşletmeleri Yönetimi, Nobel Yayınevi, Ankara.

T.C. Maliye Bakanlığ̣ Muhasebat Genel Müdürlüğü, (2007). Döner Sermayeli İşletmeler ve Bütçe ve Muhasebe Yönetmeliği, Ankara.

T.C. Sağlık Bakanlığı, Ek Ödeme ve Mali Haklar Hakkında 2012/24 Sayılı Genelge.

Yoluk, M. (2010). Hastane Performansının Veri Zarflama Analizi (VZA)Yöntemi İle Değerlendirilmesi, Atılım Üniversitesi, Sosyal Bilimler Enstitüsü, Yayınlanmış Yüksek Lisans Tezi.

04. 12.2010 Tarihli, 27775 Sayılı Resmi Gazete,Anayasa Mahkemesi Kararı.

11.03.2006 Tarihli, 26105 Sayılı Resmî Gazete,209 Sayılı Sağlık Bakanlığı'na Bağlı Sağlık Kurumları ile Esenlendirme (Rehabilitasyon) Tesislerine Verilecek Döner Sermaye Hakkında Kanun.

14.02.2013 Tarihli, 28559 Sayılı Resmi Gazete, Sağlık Bakanlığı Türkiye Kamu Hastaneleri Kurumu'na Bağlı Sağlık Tesislerinde Görevli Personele Ek Ödeme Yapılmasına Dair Yönetmelik.

18.01.2014 Tarihli, 28886 Sayılı Resmi Gazete, 6514 Sayılı Sağlık Bakanlığı ve Bağlı Kuruluşlarının Teşkilat ve Görevleri Hakkında Kanun Hükmünde Kararname İle Bazı Kanunlarda Değişiklik Yapılmasına Dair Kanun.

30.01.2010 Tarihli, 27478 Sayılı Resmi Gazete, 5947 Sayılı Üniversite ve Sağlık Personelinin Tam Gün Çalışmasına Ve Bazı Kanunlarda Değişiklik Yapılmasına Dair Kanun. 


\section{Performance Based Supplementary Payment System (PBSPS) in Health Care Businesses and Its Effects on Costs: The Case of Ankara Dışkapı Yıldırım Beyazıt Training and Research Hospital}

\author{
Seyhan ÇíL KOÇYİĞiT \\ Gazi University, \\ Faculty of Economics and Administrative \\ Sciences, Department of Healt Care \\ Management Ankara, Turkey \\ seyhanc@gazi.edu.tr
}

\author{
Nursen KARADOĞAN \\ Gazi University \\ Institute of Social Sciences \\ Department of Hospital Management \\ Ankara, Turkey \\ k.nursen12335@gmail.com
}

\section{Extensive Summary}

\section{Introduction}

The performance based supplementary payment system, which is being implemented in all the health facilities of $\mathrm{MoH}$, is the one that sets out the rates, procedures and principles of the supplementary payments to be made from the revolving fund revenues to the personnel in charge, in order to improve the health services and provide the promotion of quality and efficient service, also considering the conditions and criteria for service providing determined by the Ministry. Preliminary studies about the system were launched in 2003, with the realization of the "Transformation Program in Health". The system began to be put into practice from the beginning of 2004 in all the facilities of the $\mathrm{MoH}$, was developed over time and it survived up to now.

The performance based supplementary payment system (performance based revolving fund premium system), was influenced by the law with no. 5947 and dated 21.01.2010, also known as the "Full-Time Law" in the public. The Full-Time Law with no. 5947 and dated 21.01.2010 refers to the academic members in the universities and doctors in the public sector who will not be able to work in the private health organisations or in their own clinics and to the same whose supplementary payments shall be improved in the event that prefer to work on the public side. The effect of the Full-Time Law on the supplementary payment amounts of the health personnel and the total costs matters in this regard. The amounts of supplementary payment and total costs of MoH Dışkapı Yıldırım Beyazıt Training and Research Hospital, dated to 2009-2015 were examined in this study, as well. Additionally, the strengths and weaknesses of PBSPS were discussed.

\section{Objective}

The objective of the study is to examine the effect of the Law no. 5947 "FullTime Working of the University and Health Personnel and on Making Amendments in Certain Laws", namely the Full-Time Law, which was accepted in 21.01.2010 on the amounts of supplementary payment and total costs of MoH Dişkap1 Yildırım Beyazıt Training and Research Hospital dating to between 2009-2015. Following the enactment 
of the Full-Time Law, the change in the amounts of supplementary payment of the hospital and this change impact on the costs forms the main purpose of the study.

\section{Methods}

Data of research has been obtained to get necessary permissions from said hospital. The self-obtained financial data has been compared and the change has been interpreted in reference to the base year. In the mentioned comparison, the amounts of supplementary payment and total costs that belong to dates 2009-2015 were adjusted pursuant to the domestic PPI. The adjustment was made according to the monetary value of year 2015. Also, the amounts relating to the adjusted amounts of supplementary payment and total costs were analysed through the application of trend percentages. 2009 was taken as the base year for the trend analysis.

\section{Conclusions}

In the study, the financial data (including 2009-2015) of MoH Dışkapı Yıldırım Beyazit Training and Research Hospital was used.

In the analysis made it was understood the amounts of supplementary payment which were not adjusted to the domestic PPI increased each year, also total costs increased to except year 2011. The ratio of the amounts of supplementary payment in the total cost increased except year 2011.

After the adjustment made for the domestic PPI, it was understood that the amounts of supplementary payment with respect to base year of 2009 , decreased in 2010, 2011 and 2012, increased in 2013, 2014 and 2015. It is remarkable that the incrementation in the amounts of supplementary payment moves upward from 2013, after the enactment of the Full-Time Law in 21.01.2010. It is thought that the fixed supplementary payments to the non-doctor personnel under the Statutory Decree no.375 from July 2012 onwards, increases in the number of the personnel and promotions in the doctor, non-doctor personnel's additional indicators and gradations are among the reasons of such a boom. Also, the total costs diminished each year according to 2009 .

After adjustment made according to the domestic PPI, it was understood that the trend percentage of the amounts of supplementary payment per annum was greater than that of the total costs. It is thought that arise from to amongst the reasons that the increase in the amount of total cost is not the one which is anticipated are owed to the Service Production Cost which falls out of the supplementary payment cost item, within the total cost, other items such as the Overhead Expenses, other items pertinent to the Expenditures and Losses that belong to Other Activities and the patients'short average length of stay in hospital.

This study; perfomance based supplementary payment is a study limited to the its effects on costs in an example hospital. In addition to the performance based supplementary system increase costs, is expected to increase efficiency. Therefore, it can be said that in the continuity of this study, there is a need for studies that measure the effects of the supplementary payment system on the efficiency of the hospitals, and such studies will also contribute to the field.

Consequenlty, the performance based supplementary payment system need to be assessed as a whole, the strenghts and weaknesses of its functioning should be corrected and it should be supported with the applications that will ensure the satisfaction of the health personnel and society. 